\title{
Ergenlerde Olumlu ve Olumsuz Duygulanımın Yordanmasında Temel Psikolojik İhtiyaçlar İrrasyonel İnanışlarının Rolü
}

\author{
Predicting Positive and Negative Affect in Adolescents: The Roles of Irrational Beliefs of Basic Psychological \\ Needs
}

\author{
Murat Artıran ${ }^{\mathrm{a}^{*}}$ \\ ${ }^{a}$ Dr. Öğr. Üyesi, İstanbul Maltepe Üniversitesi, Toplum ve İnsan Bilimleri Fakültesi Psikoloji Ana Bilim Dalı, 34858, Maltepe/İstanbul \\ ORCID: 0000-0003-1996-024X
}

\section{MAKALE BİLGİSi}

\section{Makale Geçmişi:}

Başvuru tarihi: 1 Ocak 2019

Düzeltme tarihi: 15 Mart 2019

Kabul tarihi: 27 Mayıs 2019

Anahtar Kelimeler:
Ergenler,
İrrasyonel,
Psikolojik İhtiyaçlar,
Duygular

ÖZ

Öz Belirleme Kuramı, motivasyonu belirleyici olan değişkenlerin insanların yeterlilik, özerklik ve aidiyet temel psikolojik ihtiyaçları olduğunu iddia eder. $\mathrm{Bu}$ araştırmada irrasyonel ve işlevsiz düşünsel süreçler üç temel psikolojik ihtiyaç bağlamında pozitif ve negatif duygular ile birlikte sınanmıștır. Veri seti 207 katılımcının katılımıyla oluşturulmuştur. Bulgular temel psikolojik ihtiyaçlar irrasyonel inanışlarının negatif duygular ile orta derecede, pozitif duygular ile zayıf derecede ilişkili olduğunu ortaya koymuştur. Sonuçlar özerklik, yetkinlik ve aidiyet irrasyonel inanışlarının negatif duyguları, özerklik ve aidiyet psikolojik ihtiyaçları irrasyonel inanışlarının da pozitif duyguları yordadığını göstermektedir. Yetkinlik irrasyonel inanışlarının ise pozitif duyguları yordamadığı bulgulanmıştır. Sonuçlar temel psikolojik ihtiyaçların irrasyonel inanışlarının psikoloji alanında diğer değişkenlerle araştırılmasının gerekliliğini ortaya koymuştur.

\section{ARTICLE INFO}

\section{Article history:}

Received 1 January 2019

Received in revised form 15 March 2019 Accepted 27 May 2019

\section{Keywords:}

Adolescents,

İrational,

Psychological Needs,

Emotions

\section{A B S T R A C T}

Self-determination theory argues that basic psychological needs of competence, autonomy and relatedness determines motivation. In this study, irrational cognitive processes of three basic psychological needs were tested on positive and negative emotions. The study consists of 207 participants between the ages of 16-18. According to results, irrational beliefs of three basic psychology needs are moderately correlated with negative emotions and weakly related to positive emotions. Irrational beliefs of autonomy, competence and relatedness predicted negative emotions. Positive feelings were found to be predicted by irrational beliefs of autonomy and relatedness but not by irrational beliefs of competence. It can be concluded that irrational beliefs of basic psychological needs are significant variables that they should be tested with other psychological variables.

\section{Giriş}

Öz Belirlenim Kuramı (ÖBK) Ryan ve Deci (2000) tarafindan ortaya konmuş olan pozitif psikolojinin ön plana çıkan kuramlarından biridir. Temel psikolojik ihtiyaçların, insanların motive olmaları, yaşamdan memnuniyetleri (Deci ve Ryan, 1985, s. 32; 2000, s. 264) ve mutlu hissetmeleri üzerinde etkilidir (Deci, Ryan, Gagne, Leone, Usunoy ve

\footnotetext{
* Sorumlu yazar/Corresponding author

e-posta: dr.muratartiran@gmail.com
} 
Kornazheva, 2001, s. 939). ÖBK, organizmik entegrasyon kuramı (OEK) adı ile alt bir kurama sahiptir. OEK'da, Tablo 1'de gösterildiği gibi doğrusal ve aşamalı bir sürecin varlığı öne sürülmektedir. Bu süreç üç temel psikolojik ihtiyaç olan özerklik, yetkinlik ve aidiyet ihtiyaçlarının doyurulması ile soldan sağa doğru bir aşamalılık içerisinde insan davranışlarındaki motivasyonel süreçleri açıklar. Deci ve Ryan (2008, s.10) davranışçı terapideki ödül ve ceza gibi dışsal etkenlerin bireylerdeki motivasyonu sağlamada ve motivasyon süreçlerini açıklamakta yetersiz kaldığını, sağlıklı ve en etkin motivasyonun ancak içsel etkenlerden kaynaklabileceğini iddia etmektedir.

Deneysel ortamlarda kanıtlanmış olmasına rağmen ÖBK kuramı içsel etkenlerin hem hangi unsurlardan oluştuğu konusunda hem de süreç doğrusalında soldan (dışal motivasyonlar) sağa (içsel motivasyonlar) doğru gidişte bize hangi becerilerin gerektiği hakkında bilgi sağlamakta yetersiz kalabilmektedir. Örneğin OEK'nın süreç doğrusalıyla öne sürülen iddiaların, gerçek yaşam koşullarında (iş dünyası, spor vb.) dişsal motivasyonel unsuların insan davranışlarını belirleyici etkisi yani dışsal ektenlerin insanları nasıl harekete geçirdiğini açıklayamaması eleştiri almaktadır (Gagne ve Deci, 2005, s.332). Alan yazında kuramın noksan kalan bu yönlerinin test edilmesi ve kuramın geliştirilmesi üzerine birçok araştırma yayınlanmaya devam etmektedir. Buradaki araştırmada da temel psikolojik ihtiyaçlar (özerklik, yetkinlik ve aidiyet) irrasyonel (akılcı olmayan) inanışlar (Artıran, 2015, s. 72), OEK'nın doğrusal süreçlerini açıklamaya katkıda bulunması açısından incelenmiştir. OEK'nin doğrusal sürecin gerçekleştirilmesinde yani bireylerin davranışlarını içlerinden geldikleri gibi yapmalarında irrasyonel inanışların olumsuz yöndeki ilişkiselliği daha önce ortaya konmuştur. Örneğin Artıran (2015, s.80) tarafından temel psikolojik ihtiyaçlar üzerindeki irrasyonel inanışların ergenlerin sahip olduğu olumsuz psikolojik unsurlar ile ilişkiselliği bulgulanmıştır.

$\mathrm{Bu}$ unsurlar arasında anti sosyal davranış, öfke, duygusal bozukluk ve disfonksiyonel (işlevsiz) duygular vardır. Ek olarak, özerklik, yetkinlik ve aidiyet irrasyonel inanışlarının ergenlerde depresyon (Türkmen, 2018, s.47) ve sınav kaygıs1 ve mükemmelliyetçilik (Demirci, 2017, s.44-45) ile ilişkili olduğu bulgulanmıştır. Ancak bu ilişkilerde sebep-sonuç (yordayıcılık) etkisi olup olmadığı henüz test edilmemiştir.

Şekil 1. Öz Belirlenim Kuramı Organizmik Entegrasyon Süreç Doğrusalı.

\begin{tabular}{|c|c|c|c|c|c|c|}
\hline Davranış & $\begin{array}{c}\text { Öz- } \\
\text { Belirlenim } \\
\text { yok }\end{array}$ & 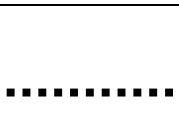 & & & & $\begin{array}{c}\text { Öz } \\
\text { Belirlenim } \\
\text { var }\end{array}$ \\
\hline Motivasyon & $\begin{array}{c}\text { Motivasyon } \\
\text { yok }\end{array}$ & & Dişsal M & vasyon & & $\begin{array}{l}\text { İçselleşmiş } \\
\text { Motivasyon }\end{array}$ \\
\hline $\begin{array}{l}\text { Motivasyonu } \\
\text { belirleyici } \\
\text { unsurlar }\end{array}$ & $\begin{array}{l}\text { Belirleyici } \\
\text { yok }\end{array}$ & $\begin{array}{c}\text { Tamamen } \\
\text { Diştan }\end{array}$ & $\begin{array}{c}\text { Çoğunlukla } \\
\text { Diştan }\end{array}$ & $\begin{array}{l}\text { Çoğunlukla } \\
\text { İçten }\end{array}$ & İçten & $\begin{array}{l}\text { Bütünüyle } \\
\text { içten gelen }\end{array}$ \\
\hline $\begin{array}{l}\text { Motivayonel } \\
\text { Süreçler }\end{array}$ & $\begin{array}{l}\text { İlgisizlik, yok } \\
\text { sayma }\end{array}$ & $\begin{array}{l}\text { Diştan } \\
\text { gelen ödül } \\
\text { ve ceza }\end{array}$ & $\begin{array}{c}\text { Ödül ve cezadan } \\
\text { dolayı kendini } \\
\text { suçlama }\end{array}$ & $\begin{array}{c}\text { Değer verme, } \\
\text { kişisel olarak } \\
\text { önem verme }\end{array}$ & $\begin{array}{c}\text { Diştan } \\
\text { gelenin içsel } \\
\text { sentezi }\end{array}$ & $\begin{array}{l}\text { İlgi, neşe, } \\
\text { tatminkarlık, } \\
\text { memnuniyet }\end{array}$ \\
\hline
\end{tabular}

Not: Şekil 1, Öz- Belirlenim Kuramı'nı ortaya koyan R. M. Ryan ve E. L. Deci’nin çeşitli yayınlarından esinlenerek hazırlanmıştır.

Albert Ellis (1962, s.28) bilişsel (düşünsel) süreçlerimizin ve duygularımızın birbirleriyle bağıntılı olduğunu keşfeden ilk bilim insanlarından biridir. Ellis'e göre bireyler, zihinlerindeki zararlı ve işlevsel olmayan düşünceleri ve inanışları rasyonel inanışlarla değiştirdiklerinde sağlıksız duygu durum ve davranışlardan arınacaklardır. İrrasyonel inanışlar Rasyonel (Akılcı) Duygucu Davranışçı Terapi'nin (RDDT) (Ellis, 1997, s.32.; Ellis \& Dryden, 1997, s.54) temel varsayımını oluşturan sağlıksız, mantıksız, katı ve gerçekçi olmayan bilişsel süreçleri ifade eder. Bu inanışlar erken çocukluk dönemlerinden itibaren, ergenlik ve yetişkinlik dönemine taşınan mantıksız, gerçekçi olmayan ve bireyi engelleyici bilişsel unsurlardır (Ellis, 1993, s.199). Psikolojik rahatsızlık içersinde olan danışanların irrasyonel inanışları RDDT'deki uygulamalar ile rasyonel inanışlara dönüştürülerek tedavi gerçekleştirilir (DiGiuseppe, Doyle, Dryden ve Backx, 2014, s.45). İrrasyonel inanışlar dörde ayrılır (1) aşırı talepkarlık, felaketleştirme/dehşetleştirme, (3) rahatsı olmaya katlanamama, (4) kendini-diğerlerini ve/veya yaşamı aşağılama/değersiz görme.

$\mathrm{Bu}$ bağlamda irrasyonel inanışlar, Artıran (2015, s.82) tarafından gerçekleştirilen Ergenler için Akılcı Duygucu Öz Belirlenim Ölçeği (ADÖB-E) çalışmasında özerklik, yeterlilik ve aidiyet temel psikolojik ihtiyaçları ile entegre edilerek (1) özerklik irrasyonel inanışları (2) yeterlilik irrasyonel inanışları ve (3) aidiyet irrasyonel inanışları olmak üzere üç ana başlık altında kavramsallaştırılmıştır. Tablo 
2'de RDDT ve ÖBK'nın unsurlarının entegrasyonunu gösteren bilgiler mevcuttur. Benzer bir çalışma Çalışanlar için Akılcı Duygucu Öz Belirlenim Ölçeği (ADÖB-Ç) ölçeği ile çalışma hayatı koşulları için gerçekleştirilmiş (Artıran, 2018, s. 28) ve üç kavramın varlığı tekrar bulgulanmıştır.

ÖBK'da belirtilen organizmik entegrasyon süreç doğrusalının soldan sağa aşamalı geçişinde özerklik, yetkinlik ve aidiyet ihtiyaçlarına bağlı olarak belirlenir. Geçişlerin önündeki engel dişsal unsurların ortadan kaldırılıp içsel unsurların etkinleştirilmesidir. Doğal olarak bunun bir yolunun da sağl1ksız düşünsel süreçlerin (örneğin irrasyonel inanışlar) sağlıklı düşünsel süreçlere dönüştürülebilmesi (örneğin rasyonel inanışlar) ile gerçekleşebileceği varsayılabilir. Dolayısıyla irrasyonel inanışların rasyonel inanışlara dönüştürülmesi sürece katkıda bulunabilir. Alan yazındaki birçok araştırma, duygu durumlarındaki bozuklukların sebepleri arasında irrasyonel inanışların rolünü ortaya koymuştur (Hyland, 2014, s. 81; DiGiuseppe, Leaf, Robin ve Gorman, 1989, 2018, s.77). Ergenler üzerinde yapılan araştırmalarda da benzer sonuçlar elde edilmiştir (Kumar, 2009, s. 105; Ngozi ve Anayochi,
2013, s. 96; Emmanuel, Gonzalez, Nelson, Gutkin, Saunders, Galloway ve Shwery, 2004, s. 233).

ÖBK'da belirtilen organizmik entegrasyon süreç doğrusalının soldan sağa aşamalı geçişinde özerklik, yetkinlik ve aidiyet ihtiyaçlarına bağlı olarak belirlenir. Geçişlerin önündeki engel dişsal unsurların ortadan kaldırılıp içsel unsurların etkinleştirilmesidir. Doğal olarak bunun bir yolunun da sağlıksız düşünsel süreçlerin (örneğin irrasyonel inanışlar) sağlıklı düşünsel süreçlere dönüştürülebilmesi (örneğin rasyonel inanışlar) ile gerçekleşebileceği varsayılabilir. Dolayısıyla irrasyonel inanışların rasyonel inanışlara dönüştürülmesi sürece kaktıda bulunabilir. Alan yazındaki birçok araştırma, duygu durumlarındaki bozuklukların sebepleri arasında irrasyonel inanışların rolünü ortaya koymuştur (Hyland, 2014, s. 81; DiGiuseppe, Leaf, Robin ve Gorman, 1989, 2018, s.77). Ergenler üzerinde yapılan araştırmalarda da benzer sonuçlar elde edilmiştir (Kumar, 2009, s. 105; Ngozi ve Anayochi, 2013, s. 96; Emmanuel, Gonzalez, Nelson, Gutkin, Saunders, Galloway ve Shwery, 2004, s. 233).

Tablo 1. ÖBK ve RDDT Unsurlarının ADÖB-E Ölçeği ile Birlikte Değerlendirilmesi.

Aşırı Talepkarlık
irrasyonel
inanışları

Özerklik ihtiyacı

Özerklik ihtiyacı aşırı talepkarlık irrasyonel inanışları

Felaketleştirme
irrasyonel
inanışları

Rahatsızlığa
Katlanamama
irrasyonel inanışları

Özerklik ihtiyacı felaketleştirme irrasyonel inanışları

Yetkinlik ihtiyacı

Yetkinlik ihtiyacı aşırı talepkarlık irrasyonel inanışları

Yetkinlik ihtiyacı felaketleştirme irrasyonel inanışları

Aidiyet ihtiyacı aşırı talepkarlık irrasyonel inanışları
Aidiyet ihtiyacı

felaketleştirme irrasyonel inanışları

\begin{abstract}
Özerklik ihtiyacı
Rahatsızlığa

katlanamamak

irrasyonel inanışları
\end{abstract}

Yetkinlik ihtiyacı

Rahatsızlığa

katlanamamak

irrasyonel inanışları

Aidiyet ihtiyacı
Rahatsızlığa
katlanamamak
irrasyonel inanışları

\section{Kendini / \\ diğerlerinin / \\ yaşamı aşağılama irrasyonel inanışları}

Özerklik ihtiyacı

kendini/ diğerlerinin

/ yaşamı aşağılama

irrasyonel inanışları

Yetkinlik ihtiyacı

kendini/ diğerlerinin

/ yaşamı aşağılama

irrasyonel inanışları

Aidiyet ihtiyac

kendini/ diğerlerinin

/ yaşamı aşağılama

irrasyonel inanışları
ÖBK'da özerklik temel psikolojik ihtiyacı, kişinin içinden geldiği gibi hareket etmesi, kendi kararlarının özgürce vermesi ve sorumluluklarını alarak kendi davranışlarının kendisinin yönetebilmesi anlamına gelmektedir. Yetkinlik ihtiyacı ise bireyin yaptığı faaliyetlerde yeterli olması ve daha da ötesi hayatta ustalaşması demektir. Aidiyet ihtiyacı ise ilişkiselliği işaret eder ve bireyin çevresindeki diğer insanlarla iyi ve sıcak ilişkiler geliştirmesini tanımlar. Bu tanımlar, ÖBK kuramcıları olan Ryan ve Deci tarafindan oluşturulmuş ve deneysel ve deneysel olmayan birçok araştırmada test edilmiştir (Deci ve Ryan, 2008, s.2; Özer ve Altun, 2011, s. 70). Temel psikolojik ihtiyaçların Pozitif ve negatif duygular üzerindeki etkililiği (Reed ve Ones, 2006, s.512) ve motivasyon (Lyubomirsky, King ve Diener, 2005, s.360) ile ilişkiselliği daha önce bulgulanmıştır. Bu araştırmada pozitif ve negatif duygular ile $\ddot{u} c ̧$ temel psikolojik ihtiyaç irrasyonel inanışların ilişkiselliği ergenlik çağındaki bireyler üzerinde incelenmiştir. Ek olarak söz konusu değişkenlerin pozitif ve negatif duyguları üzerinde etkisinin olup olmadığ 1 test edilmiştir. İrrasyonel inanışların özerklik, yetkinlik ve aidiyet ihtiyaçlarını karşılamada rasyonel inanışlara dönüştürülebilmesi pozitif duyguların kazanılması ve negatif duyguların giderilmesini sağlayacağı varsayımının bu araştırmanın hipotezinin doğrulanması ile geçerlilik kazanabileceği düşünülmektedir. Elbetteki bu yöndeki araştırmaların daha farklı örneklem grubunda test edilmesinin devam edilmesine ihtiyaç olacaktır.

$\mathrm{Bu}$ araştırmanı hipotezleri sırasıyla şöyledir: (1) Özerklik ihtiyacı irrasyonel inanışları pozitif ve negatif duyguları yordamaktadır, (2) yeterlilik ihtiyacı irrasyonel inanışları pozitif ve negatif duyguları yordamaktadır, (3) aidiyet irrasyonel inanışları pozitif ve negatif duyguları yordamaktadır. $\mathrm{Bu}$ hipotezlerin doğrulanması halinde, alanyazında hali hazırda insan davranış, duygu ve düşünce süreçlerini açıklamaya çalışan iki kuramın (RDDT ve ÖBK) var olan varsayımlarını destekleyen ve ötesinde, psikolojik danışmanlık süreçlerinde entegratif bir anlayış getirerek ergenlerin psikolojik sorunlarına daha ekonomik çözümler üretilmesinde katkı sağlayacaktır. Davranış, duygu ve düşünceleri daha geniş alanlarda açıklayan bir kavram ortaya 
konulmuş olacaktır. Bu, her iki kuramın yetersiz kaldığından ve bir noksanlı̆̆ı gidereceğinden değil, daha çok, daha ekonomik ve yapılandırılmış bir modelin ortaya konması için atılmış bir adım olarak sayılabilir.

\section{Yöntem}

\subsection{Verilerin Analizi}

Verilerin normal dağılıp dağılmadığının kontrolü için Kolmogorov Smirnov testi analizi sonuçlarına bakılmıştır. Verilerin normal dağılım gösterip göstermediğini incelemek için çarpıklık ve basıklık değerleri hesap edilmiştir. Bu değerlerin +1.0 -1.0 (Hair, Black, Babin, Anderson \& Tatham, 2013) veya -2 ile +2 arasında olması verilerin normal dağılımı için kabul edilebilir sınırlarda olduğunu gösterir (Kalayc1 2014: 209; Garson 2008: 18-19). Bu çalışmada analiz sonuçları çarpıklık ve basıklık değerleri -1 ile +1 aralığındadır. $\mathrm{Bu}$ araştırma nicel bir çalışmadır ve ilişskisel tarama modeli kullanılarak gerçekleştirilmiştir. Veriler üzerinde SPSS 20.0 programı kullanılarak korelasyon ve çoklu regresyon analizleri yapılmıştır. Korelasyon sonuçlarını test etmek için Pearson Momentler Korelasyon analizi kullanılmıştır. Korelasyon sonuçlarını değerlendirilmesinde (r) 00-.19 "çok zayıf”, .20-.39 “zayıf”, .40-.59 “orta", .60-.79 "güçlü” ve .80-1.0 "çok güçlü” (Evans, 1996) değerleri gözetilmiştir. Çoklu regresyon analizi 'enter' yöntemiyle gerçekleştirilmiştir. Bu yöntemde tüm bağımsız değişkenler regresyon eşitliğine aynı anda sokulur. Çoklu regresyon analizlerinde değişkenler arasında otokorelasyon olup olmadığına bakılmış, bunu ölçen Durbin Watson istatistiği analizleri gerçekleştirilmiştir. Bu istatistik çoklu regresyon analizlerinin doğru değerler verip vermediğinin sınanması için 0 ile 4 arasında yer almalıdır (King ve David, 1995, s. 489).

\subsection{Evren ve Örneklem}

Araştırmanın evreni, İstanbul ilindeki özel liselerde öğrenim gören ve ayrıca eş zamanlı olarak özel yabancı dil kurslarında giden öğrencilerden oluşmaktadır. Örneklem ise evrenin içinden uygun örnekleme yöntemi ile seçilen 93'ü kız (\%44.9) ve 114’ü erkek (\%55.1) olmak üzere 207 ergenlik çağındaki bireyden oluşmuştur. Birçok araştırma için 30 ila 500 arası örneklem büyüklüklüğü uygundur (Büyüköztürk, Çakmak, Akgün, Karadeniz ve Demirel, 2008). Çok değişkenli bir araştırmada (örn. regresyon analizleri), örneklem büyüklüğü çalışmadaki değişken sayısının tercihen 10 katı veya daha fazla olmalıdır (Büyüköztürk, 2011). Bu araştırmada 5 değişken vardır, dolayısıyla örneklem büyüklüğü yeterlidir. Bu yaş grubunun seçilmesinin nedeni kullanılan ölçeklerden biri olan Akılcı Duygucu Öz Belirlenim Ölçeği'nin (ADÖB-E) ergenler için geliştirilmiş olmasıdır. İrrasyonel inanışların erken gelişim dönemde oluşmaya başlaması nedeniyle (Çivitçi \& Çivitçi, 2009; Çivitçi, 2009) araştırmanın da bu grup üzerinde yapılması geleceğe yönelik genelleştirilebilen öngörülerin oluşturulmasında katkı sağlayacağı düşünüldü. Araştırma verilerinin toplanması için velilerinden ve kendilerinden bilgilendirilmiş onam formu okunarak imzalı izin alınmıştır. Katılımcıların yaş ortalaması $17.08^{\prime}$ dir (SS: .7555). Yaş aralığg 16-18'dir. Betimsel istatistiki verilere göre öğrencilerin ailelerinin toplam geliri sırasıyla $3000 \mathrm{TL}$ ve altı, 98 öğrenci (\%47.3), 3000-5000 TL arası, 65 öğrenci
(\%31.4) ve 5000 TL ve üstü 44 öğrenci (\%21.3) olarak bulgulanmıştır.

\subsection{Veri Toplama Araçları \\ 2.3.1. Ergenler için Akılcı Duygucu Öz Belirlenim Ölçeği $(A D O ̈ B-E)$}

Artıran (2015) tarafından geliştirilen ölçek bilişsel davranışçı terapilerin $\mathrm{ABC}$ modeline $(\mathrm{A}=$ Harekete geçirici olay, $B=$ İnanışlar ve Düşünceler, $C=$ Duygular ve Davranışlar) uygun olarak tasarlanmıştır. Rasyonel duygucu davranışçı terapinin ana unsurları olan dört irrasyonel inanışı, öz belirlenim kuramında belirtilen üç temel psikolojik ihtiyaç (özerklik, yeterlilik, aidiyet ihtiyaçları) temelinde ölçmektedir. 51 maddeden oluşan ölçeğin 18 maddesi özerklik ihtiyacı irrasyonel inanışlarını (Özİrr) (iç tutarlılık katsayısı $=.90), 18$ maddesi aidiyet ihtiyacı irrasyonel inanışlarını (Aitİrr) (iç tutarlılık katsayısı $=.85$ ) ve 15 maddesi ise yeterlilik ihtiyacı irrasyonel inanışlarını (Yetİrr) (iç tutarlılık katsayısı = .90) ölçmektedir.

Örneğin, ölçekte katılımcılara özerklik ihtiyacı irrasyonel inanışları için olay (A) olarak ' $\mathrm{Ne}$ zaman ders çalışmam gerektiği konusuna annem ve/veya babam karışıyor' verilmekte ve bu durum karşısında ne düşündüklerini/inandıklarını ölçmek için 'Karışıp durmalarına katlanamiyorum (rahatsız olmaya katlanamamak irrasyonel inanışı) veya 'Böyle durumlarda değersiz biri olduğumu düşünüyorum' (kendini değersizleştirme irrasyonel inanışı) gibi ifadeleri 5'li likert ölçeğine göre değerlendirmeleri istenmektedir. Öçekten alınan yüksek puanlar öğrencinin temel psikolojik ihtiyaçlarını karşılamada irrasyonel inanışlara sahip olduğunu göstermektedir. $\mathrm{Bu}$ durumun da öğrencide sağlıksız duygu ve davranışlara neden olabileceği ön görülmektedir. Dış kriter geçerliliği çalışmasında ADÖBE'nin Reynolds'un Ergenler İçin Uyum Süreçleri Taraması Ölçeği (REIDTÖ), Duygu Durum Rahatsızlıkları Profili Ölçeği (DDRP), anne ve babadan algılanan Temel Psikolojik İhtiyaçlar Ölçeği (TPİÖ) ile zayıf ve orta düzey arasında korelasyon değerleri verdiği bulgulanmıştır. Bu çalışmada ölçeğin güvenilirlik analizlerinde sırasıyla özerklik ihtiyacı irrasyonel inanışları boyutu .92, aidiyet ihtiyacı irrasyonel inanışı boyutu .90 ve yeterlilik ihtiyacı irrasyonel inanışı boyutu .87 iç tutarlılık (cronbach alpha) katsayısı hesaplanmıştır.

\subsubsection{Pozitif ve Negatif Duygu Ölçeği (PANAS)}

Watson ve Clark (1988) tarafindan geliştirilen ölçeğin Türkçe uyarlama çalışması Gençöz (2000) tarafindan yapılmıştır. 5'li Likert ölçeği ile katılımcıların pozitif ve negatif duygu durumlarını ölçmektedir. Ölçekte yer alan toplam 20 duygu durumdan bazı pozitif duygular arasında, ilgili, güçlü, hevesli; bazı negatif duygular arasında suçlu, sıkıntılı ve ürkmüş gibi maddeler vardır. Katılımcılardan bu duyguları ne oradan hissettikleri sorulmaktadır. Ölçeğin iç tutarlılık (Cronbach Alpha) değerleri pozitif duygular için .88 ve negatif duygular için .85 olarak hesaplanmıştır. $\mathrm{Bu}$ araştırmada da iç tutaarlılık katsayıları negatif duygular için .75 ve pozitif duygular için .81 olarak bulgulanmıştır. 


\subsection{Bulgular ve Yorumlar}

Araştırma örnekleminden elde edilen verilerin normal dağıldığı gözlemlenmiştir. Çoklu regresyon analizi yapmadan önce korelasyon analizleri gerçekleştirilmiştir. Sonuçlara göre negatif duygular ile temel psikolojik ihtiyaçlar irrasyonel inanışları arasında orta derecede anlamlı
( $p<.001)$ ilişkilerin bulunduğu gözlemlenmiștir (Tablo 3). Pozitif duygular ile ise söz konusu değişkenlerin zayıf düzeyde anlamlı ilişkisellik gösterdiği bulgulanmıştır $(p<.001)$

Tablo 2. Korelasyon Analizleri

\begin{tabular}{|c|c|c|c|c|c|c|c|}
\hline Değişkenler & Ort. & $\mathrm{SS}$ & 1 & 2 & 3 & 4 & 5 \\
\hline $\begin{array}{l}\text { 1- Özerklik ihtiyacı } \\
\text { irrasyonel inanışları }\end{array}$ & 49.74 & 15.80 & 1 & & & & \\
\hline $\begin{array}{l}\text { 2-Yeterlilik ihtiyacı } \\
\text { irrasyonel inanışları }\end{array}$ & 38.71 & 11.84 & $.28 * *$ & 1 & & & \\
\hline $\begin{array}{l}\text { 3-A aidiyet ihtiyacı } \\
\text { irrasyonel inanışları }\end{array}$ & 47.43 & 14.57 & $.32 * *$ & $.54 * *$ & 1 & & \\
\hline 4- Pozitifi Duygular & 42.37 & 7.98 & $-.31 * *$ & $-.22 * *$ & $-.30 * *$ & 1 & \\
\hline 5-Negatif Duygular & 32.31 & 11.67 & $.47 * *$ & $.50 * *$ & $.46^{* *}$ & $-.42 * *$ & 1 \\
\hline
\end{tabular}

Not: $* * p<.001 . \mathrm{N}=194$ (negatif duygular), $\mathrm{N}=207$ (pozitif duygular). Ort. = puan ortalamları, SS: Standart Sapma değerleri. Özerklik ihtiyacı irrasyonel inanışları, aidiyet ihtiyacı irrasyonel inanışlarını ve yeterlilik ihtiyacı irrasyonel inanışları, ADÖB-E (Artıran, 2015) ölçeğinin üç boyutunu ifade etmektedir.

\subsubsection{Regresyon Analizleri}

Korelasyon analizlerinin ardından bulguların doğrusal çoklu regresyon analizleri yapılması için yeterli olduğu görülmüştür. $\mathrm{Bu}$ araştırmada Durbin Watson istatistiği, negatif duyguların yordanmasını ölçen modelde 1.627, pozitif duyguların yordanmasını ölçen modelde 0.009 olarak bulgulanmıştır. Ĕger istatistik Durbin Watson değeri 2 civarında ise, korelasyon olmadığı şeklinde yorumlanır, 0'a yakın değerler yüksek pozitif korelasyonu belirtir (Montgomery, Peck, ve Vining, 2001, s. 71). Çoklu regresyon analizlerinde özerklik, yeterlilik ve aidiyet ihtiyaçları irrasyonel inanışları değerlerinin pozitif ve negatif duyguları anlamlı bir düzeyde yordayıp yordamadığı incelenmiştir, bulgular Tablo 4 ve 5 'te sunulmuştur. Pozitif duyguların bağımlı değişken olduğu regresyon $\left(R^{2}=.145\right)$ eşitliği anlamlıdır $(F(3,203)=11.461, p<.005)$. Negatif duyguların bağımlı değişken olduğu regresyon eşitliği $\left(\mathrm{R}^{2}=\right.$ $.375)$ de anlamlidir $(F(3,190)=37.943, \quad p<.005)$. Katılımcıların negatif duygularını sırasıyla özerklik ihtiyaçları irrasyonel inanışları .152 birim, aidiyet ihtiyaçları irrasyonel inanışlarını .233 birim ve yeterlilik ihtiyaçları irrasyonel inanışlarını ise .286 birim artırmaktadır. Her üç psikolojik ihtiyaç irrasyonel inanışları, negatif duyguları yordamaktadır (Tablo 4). Katılımcıların pozitif duygularını sırasıyla özerklik ihtiyaçları irrasyonel inanışları -.111 birim, aidiyet ihtiyaçları irrasyonel inanışları -.120 birim azaltmaktadır. Özerklik ve aidiyet ihtiyaçları irrasyonel inanışları pozitif duyguları yordamaktayken yeterlilik ihtiyacı irrasyonel inanışları ise pozitif duyguları yordamamaktadır (Tablo 5).
Tablo 4. Negatif Duyguların Yordayıcıları.

\begin{tabular}{lclccc}
\hline Yordayıc1ar & B & Std.Hata & $\beta$ & $t$ & $P$ \\
\hline Sabit (a) & 2.570 & 2.872 & & .895 & .372 \\
Özİrr & .152 & .057 & .190 & 2.676 & .008 \\
Yeṫ̇rr & .286 & .071 & .284 & 4.003 & .000 \\
Aiṫ̇̇r & .233 & .046 & .313 & 5.055 & .000 \\
\hline
\end{tabular}

Tablo 5. Pozitif Duyguların Yordayıcıları

\begin{tabular}{lcllcc}
\hline Yordayıcılar & B & Std.Hata & \multicolumn{1}{c}{$\beta$} & \multicolumn{1}{c}{$t$} & \multicolumn{1}{c}{$P$} \\
\hline Sabit (a) & 54.677 & 2.241 & & 24.395 & .000 \\
Özİrr & & & - & & \\
& -.111 & .043 & .203 & -2.587 & .010 \\
Yetİrr & & & - & & \\
& -.028 & .052 & -.042 & -.540 & .590 \\
Aitİrr & & & - & & \\
& -.120 & .035 & .238 & -3.441 & .001 \\
\hline
\end{tabular}

Bağımlı değişken: Pozitif Duygular

\section{Sonuç}

Organizmik entegrasyon kuramı, motivasyonel süreçlerle ilgili olarak, insanların kendilerini daha özerk, kontrolde ve yeterli hissetmelerine yardımcı olan bir varsayını ortaya atar (Ryan ve Connell, 1989, s. 751). Süreçte dişsal motivasyonlarla güdülenen bireylerin içsel motivasyonlarla güdülenebilmeleri için kendileri ile barışık olmaları, işlevsel davranışlara sahip olmaları ve çevreleri ile uyumlu olmaları (Deci ve Ryan, 2000, s. 54) gerekmektedir. Pozitif ve negatif duygu durumun insan davanışlarındaki rolü tartışmasızdır. 
$\mathrm{Bu}$ araştırmada temel psikolojik irrasyonel inanışlarının duygulara etkisi test edilmiştir. Bulgular irrasyonel inanışların üç temel psikolojik ihtiyaç bağlamında pozitif ve negatif duygularla ilişkili olduğunu ortaya koymuştur. Rasyonel inanışların insanlardaki negatif duyguları azalttığ ve pozitif duyguları da desteklediği daha önceki araştırmalarda bulgulanmıştır (Zakiei, Karami, Alikhani, Ghasemi ve Gilan, 2013, s. 397). Bu araştırmada da üç temel psikolojik ihtiyaç bağlamında irrasyonel inanışların pozitif ve negatif duyguları etkisi yani bu değişkenleri yordayıp yordamadığı da incelenmiştir. Bulgulara göre böyle bir etkiden söz edilebilir.

Dolayısıyla Artıran (2015, s. 92) tarafindan ortaya konan RDDT ve ÖBK kuramlarının entegrasyonunun organizmik entegrasyon doğrusal süreçlerine olumlu katkısı olabileceği iddia edilebilir. Ancak bu varsayımın gelecekteki araştırmalarda tekrar test edilmesi ve özellikle deneysel çalışmalarla terapötik ortamlarda denenmesi gerekliliğinden bahsedilebilir.

ÖBK alan yazınında temel psikolojik ihtiyaçların pozitif ve negatif duygular ve psikolojik iyi oluş (Ryan \& Deci, 2000, Baard, Deci, \& Ryan, 2004), motivasyon (Gagne ve Deci, 2005) ve tatminkarlık (Arshadi, 2010; Sexton, 2013) ile ilişkili olduğu bulgulanmıştır. Sheldon, Kasser, Smith ve Share'in (2002, s. 27) çalışması ÖBK unsurlarının deneysel olarak uygulanabilirliğini gösteren bir çalışmadır. Bu çalışmada katılımcıların duygu durumları (pozitif ve negatif) ÖBK unsurları ile oluşturulan programda sınanmış ve sonuçlar bu araştırmanın sonuçlarını destekler nitelikte çıkmıştır. 60-90 yaş arası katılımcılar üzerinde gerçekleştirilen benzer bir deneysel çalışmada da (Antunes, Moutao, Marinho ve Cid, 2018, s. 5) PANAS ölçeği kullanılmış ve bulgulara göre katılımcıların pozitif duygularının arttığı, negatif duygularının azaldığı gözlemlenmiştir. Bu çalışmada alan yazına bir katkı olarak ÖBK unsurları RDDT unsurları ile genişletilmiş ve sonuçlar değerlendirilmiştir. Sonuç olarak bu çalışmanın hipotezleri doğrulanmıştır.

RDDT ve ÖBK unsularının bileşkesinin bir ifadesi olarak üç temel psikolojik ihtiyaç (özerklik, yeterlilik ve aidiyet ihtiyacı) irrasyonel inanışlarının pozitif ve negatif duygudurum üzerinde etkili olduğu ortaya konulmuştur. Bu etkinin olmadığı yordayıcılık ilişkisi sadece yeterlilik irrasyonel inanışları ile pozitif duygu durum arasında yoktur. Bunun bir sebebi olarak ÖBK kuramında özerklik ihtiyaçlarının diğer psikolojik ihtiyaçlara göre çok daha etkin düzeyde olduğu, yeterlilik ve aidiyet ihtiyaçlarının ise ikincil geldiğinin görülmekte olduğu söylenebilir (Collins \& Repinski, 1994; Youniss \& Smollar, 1985), dolayısıyla bu çalışmanın sonuçlarına göre de kuram üzerinde gelecekteki araştırmaların devam etmesi gerektiğine dair bir sonuç çıkarılabilir. Özerklik, yetkinlik ve aidiyet ihtiyaçları irrasyonel inanışları henüz yeni bir kavramdır ve üzerinde gerçekleştirilmiş az sayıda bilimsel çalışma vardır. Araştırmanın sınırlıkları arasında örneklem büyüklüğü, yetkinlik ihtiyacı irrasyonel inanışlarının neden pozitif duyguları yordamadığının açıklanamaması ve verilerin klinik ortamda toplanmış olmaması gösterilebilir.

Özetle, sonuçlara göre, ergenlerin temel psikolojik ihtiyaçlarının karşılanmasında bilişsel yapılarındaki irrasyonel inanışların çürütülmesi negatif duyguları azaltacak etki yaratabilecektir. Özerklik ve aidiyet psikolojik ihtiyaçlarının ise pozitif duyguları yordadığı ortaya konmuştur. Dolayısıyla duyguların insan psikolojisindeki (örn. anksiyete ve depresyon) belirleyici rolü düşünüldüğünde (Watson, Clark \& Carey, 1988; Anas \& Akhouri, 2013) gerek bireysel psikolojik danışmanlık süreçlerinde gerekse de okul ortamlarında gerçekleştirilecek önleyici uygulamalarda, ergenlerin temel psikoloji ihtiyaçlar irrasyonel inanışları üzerinde yapılacak çalışmaların yer alması yarar sağlayacaktır.

\section{Kaynakça}

Anas, M. \& Akhouri, D. (2013). Positive And Negative Affect In Depressed And Normal Adults. ISSN: 09735755. 8. 61-68.

Antunes, N., Moutão, J., Marinho, D. \& Cid, L. (2018). Goal Content for the Practice of Physical Activity. Journal of Ageing Science, 6:1. DOI: 10.4172/2329-8847.1000189

Arshadi, N. (2010). Basic need satisfaction, work motivation, and job performance in an industrial company in Iran. Procedia - Social and Behavioral Sciences, 5, 1267-1272.

Artıran, M. (2015). Akılcı Duygucu Davranışçı Kuram Ve Öz-Belirlenim Kuramı Çerçevesinde Yeni Bir Ölçek: Aklcl-Duygucu Öz-Belirlenim (ADÖB) Ölçeği'nin Geliştirilmesi - Doktora Tezi. Istanbul Arel University, Turkey.

Büyüköztürk, Ş. (2011). Sosyal bilimler için veri analizi el kitabı. Ankara: Pegem Akademi Yayıncılık.

Büyüköztürk, Ş., Çakmak, E. K., Akgün, Ö. E., Karadeniz, Ş. ve Demirel, F. (2008). Bilimsel araştırma yöntemleri. Ankara: Pegem Akademi.

Çivitci, Asim. (2009). Relationship between Irrational Beliefs and Life Satisfaction in Early Adolescents. Eurasian Journal of Educational Research (EJER). 9. 91109.

Çivitçi, A., \& Çivitçi, N. (2009). Perceived social skills and irrational beliefs in primary school students. Elementary Education Online, 8(2), 415-424.

Collins, W. A., \& Repinski, D. J. (1994). Relationships during adolescence: Continuity and change in interpersonal perspective. In R. Montemayor, G. Adams, \& T. Gullotta (Eds.), Advances in adolescent development: Vol. 5. Personal relationships during adolescence (pp. 7-36). Thousand Oaks, CA: Sage.

Gagne, M., \& Deci, E. L. (2005). Self-determination theory and work motivation. Journal of Organizational Behavior, 26, 331-362. doi: 10.1002/job.322

Gençöz, T. (2000). Pozitif ve Negatif Duygu Ölçeği: Geçerlik ve güvenirlik çalışması. Türk Psikoloji Dergisi, 15(46), 19-26.

Deci, E. L; Ryan, R. M. (2008). Hedonia, Eudaimonia, And Well-Being: An Introduction Journal of Happiness Studies, 9:1-11. DOI 10.1007/s10902-006-9018-1

Deci, E. L., Ryan, R. M., Gagné, M., Leone, D. R., Usunov, J., \& Kornazheva, B. P. (2001). Need Satisfaction, 
Motivation, and Well-Being in the Work Organizations of a Former Eastern Bloc Country: A Cross-Cultural Study of Self-Determination. Personality and Social Psychology Bulletin, 27(8), 930-942. https://doi.org/10.1177/0146167201278002

DiGiuseppe, R. A., Doyle, K. A., Dryden, W., Backx, W. (2017). Rasyonel Duygucu Davranışçı Terapi Uygulamaclsının Bir Kllavuzu. (Çeviren ve Türkçe Editörü: M. Artıran). Nobel Yayınları. İstanbul.

DiGiuseppe, R., Leaf, R., Gorman, B., \& Robin, M. W. (2018). The Development of a Measure of Irrational/Rational Beliefs. Journal of Rational-Emotive \& Cognitive-Behaviour Therapy, 36(1), 47-79.

Ellis, A. (1962). Reason and emotion in psychotherapy. New York: L. Stuart.

Ellis, A. (1993). Reflections on rational-emotive therapy. Journal of Consulting and Clinical Psychology, 61(2), 199-201.

Emmanuel, O., Ngozi, U., \& Anayochi, N. (2013). Effects of Rational Emotive Behaviour Therapy and Emotional Intelligence on Mathematics Anxiety of In- School Adolescents in Owerri Municipal Nigeria. European Journal Of Sustainable Development, 2(3), 85-98.

Evans, J. D. (1996). Straightforward statistics for the behavioral sciences. Pacific Grove, CA: Brooks/Cole Publishing.

Garson, D.G. (2008). Testing Statistical Assumptions, North Carolina Stat University, Statistical Associates

Publishing, Blue Book Series. Gonzalez, J., Nelson, J., Gutkin, T., Saunders, A., Galloway, A., \& Shwery, C. (2004). Rational Emotive Therapy With Children and Adolescents: A Meta-Analysis. Journal Of Emotional And Behavioral Disorders, 12(4), 222-235. doi:10.1177/10634266040120040301

Hair, J. F., Black, W. C., Babin, B. J., Anderson, R. E., \& Tatham, R. L. (2013). Multivariate Data Analysis. Pearson Education Limited.

Hyland, P. (2014). A rational emotive behaviour therapy perspective on the nature and structure of posttraumatic stress responses: The mediating and moderating effects of rational and irrational beliefs (Doctoral dissertation). University of Ulster, United Kingdom.

King, M. \& David, H. C. (1995). The application of the durbin-watson test to the dynamic regression model under normal and non-normal errors. Econometric Reviews, $14 . \quad 487-510 . \quad$ doi: $10.1080 / 07474939508800333$.

Kumar, G. V. (2009). Impact of Rational-Emotive Behaviour Therapy (REBT) on Adolescents with Conduct Disorder (CD). Journal of the Indian Academy of Applied Psychology, Vol. 35, Special Issue, 103-111.
Montgomery, D. C., Peck, E. A. and Vining, G. G. (2001). Introduction to Linear Regression Analysis. 3rd Edition, New York, New York: John Wiley \& Sons.

Kalaycı, Şeref (2014). SPSS Uygulamalı Çok Değişkenli Istatistik Teknikleri. Ankara: Asil Yayın Dağıtım 6. Bask1.

Lyubomirsky S, King L, Diener E. (2005). The benefits of frequent positive affect: does happiness lead to success? Psychological Bulletin, 131:803-55.

Özer, A., \& Altun, E. (2011). The Reasons for Academic Procrastination Among University Students. Mehmet Akif Ersoy Üniversitesi Ë̆itim Fakültesi Dergisi, 11.21, 45-72.

Reed, J. \& Ones, D.S. (2006). The effect of acute aerobic exercise on positive activated affect: a meta-analysis. Psychology of Sport and Exercise, 7:477-514.

Ryan, R. M. \& Connell, J. P. ( 1989). Perceived locus of causality and internalization: Examining reason for acting in two domains. Journal of Personality and Social Psychology, 57, 749-761.

Ryan, R. M., \& Deci, E. L. (2000). Intrinsic and extrinsic motivations: Classic definitions and new directions. Contemporary Educational Psychology, 25(1), 54-67.

Sexton, J. (2013). The application of self-determination theory to employee motivation in Irish workplaces. Submitted in partial fulfillment of the requirements of the Post-Graduate Higher Diploma in Psychology at DBS School of Arts, Dublin, Ireland.

Sheldon, K. M., Kasser, T., Smith, K. \& Share, T. (2002). Personal Goals and Psychological Growth: Testing an Intervention to Enchange Goal Attainment and Personality Integration. Journal of Personality, 70:1.

Smollar, J., \& Youniss, J. (1989). Transformations in adolescents' perceptions of parents. International Journal of Behavioral Development, 12(1), 71-84.

Watson, D., Clark, L. A., \& Tellegen, A. (1988). Development and validation of brief measures of positive and negative affect: the PANAS scales. Journal of personality and social psychology, 54(6), 1063-1070.

Watson, D., Clark, L. A., \& Carey, G. (1988). Positive and negative affectivity and their relation to anxiety and depressive disorders. Journal of abnormal psychology, 97(3), 346.

Zakiei, A., Karami, J., Alikhani, M., Ghasemi, S. R. \& Gilani, N. R. (2013). The relationship between alexithymia, irrational beliefs, positive and negative emotions with mental disorders. Hormozgan Medical Journal, Vol 18, No. 5. 